\title{
ANALYSIS OF THE APPLICATION OF DISTRIBUTED PROPULSION TO THE AOS H2 MOTOR GLIDER
}

\author{
Michał Kuźniar, Marek Orkisz \\ Rzeszow University of Technology, Faculty of Mechanical Engineering and Aeronautics \\ Department of Aircraft and Aircraft Engines \\ Powstańców Warszawy Av. 8, 35-959 Rzeszow, Poland \\ tel.: +48178651466 \\ e-mail:mkuzniar@prz.edu.pl,mareko@prz.edu.pl
}

\begin{abstract}
The paper describes the selection of a distributed propulsion for the AOS H2 motor glider (selection of engines, their number, and propellers) and determination of its performance. This analysis is related to the research conducted on environment friendly and hybrid propulsions in various research centres. The main aim of the analyses conducted is to increase the performance of vehicles powered by electric motors. The batteries have a low density of energy, i.e. the ratio of mass to cumulated energy. Instead of a battery set, it is possible to apply a hybrid-electric system, where the combustion engine works as a generator or an electric-hydrogen generator, where the hydrogen cell supports a small set of batteries. One of such flying vehicles, fitting in this trend, is the AOS H2 motor glider built at the Rzeszow University of Technology in cooperation with other universities. It is a hybrid aircraft, equipped with a hydrogen cell, which together with a set of batteries is a source of electricity for the Emrax 268 electric motor. To increase the vehicle's performance (the range and flight duration), it is possible to use a distributed propulsion. This type of propulsion consists in placing many electric motors along the wingspan of the aircraft. Appropriate design of such a system (propeller diameters, engine power, number of engines) can improve the aerodynamic and performance parameters of the airframe. An analysis of the performance for the selected flight trajectory for this propulsion variant was conducted and compared to the performance of the AOS H2 motor glider equipped with traditional propulsion. The consumption of hydrogen was also determined for both systems. The results obtained were presented in the diagrams and discussed in the conclusions.
\end{abstract}

Keywords: Aircraft Engineering, Engines, Mechanical Engineering

\section{Introduction}

In air transport, attention is increasingly paid to the issues related to ecological aspects of exploitation. Reduction of emissions of harmful compounds and fuel consumption is achieved by improving and developing existing structures as well as creating new ones (Pipistrel Panthera, Boeing Phenom) [3, 8]. One of such methods is the use of electric propulsions for aircraft propulsion. Propulsions of this type are easier to integrate with the airframe, provide more favourable propulsion characteristics for propellers and a favourable mass and size ratio in relation to the power developed. The biggest problem associated with this type of propulsions is the energy source. Currently available batteries are heavy and, consequently, provide a low density of energy accumulated on board. This affects the performance of the aircraft, such as the flight range and duration. In order to improve the performance indicators, research has been conducted on other power sources (hybrid propulsion using hydrogen cells) or distributed propulsion to improve the aerodynamic performance of the propulsion. The paper presents an analysis of the application of distributed propulsion to the propulsion of AOS H2 hybrid glider and possible benefits of such a solution.

\section{The research object}

As mentioned, the research object is the AOS H2 motor glider. This is an experimental construction of a motor glider with hybrid propulsion using a hydrogen cell. The fuel cell generates 
sufficient power to power the marching motor (the EMRAX 268 three-phase electric motor), and the auxiliary battery assembly is additionally used for the take-off. Fig. 1 shows a schematic view of a motor glider and its technical data are given in Tab. 1.

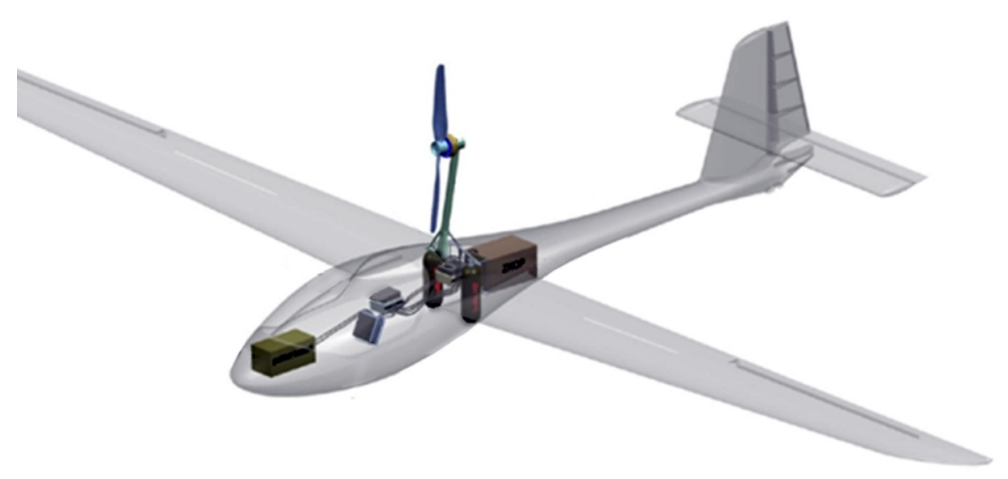

Fig. 1. The AOS H2

The motor glider is being built in cooperation between Rzeszow University of Technology, Warsaw University of Technology and AGH University of Science and Technology.

Tab. 1. Technical data of the AOS H2 [6, 7]

\begin{tabular}{|l|c|c|}
\hline Wing area & $\mathrm{S}\left[\mathrm{m}^{2}\right]$ & 15.8 \\
\hline Wing span & $\mathrm{R}[\mathrm{m}]$ & 16.4 \\
\hline Aspect ratio & $\Lambda$ & 17 \\
\hline Maximum take-off mass & $\mathrm{M}_{\max }[\mathrm{kg}]$ & 660 \\
\hline Minimum motor glider mass & $\mathrm{M}_{\min }[\mathrm{kg}]$ & 500 \\
\hline
\end{tabular}

The Fig. 2 shows the power required for flight of the motor glider as a function of flight speed. On the basis of this data, the distributed propulsion was selected, and the obtained performance was compared to a traditional power unit.

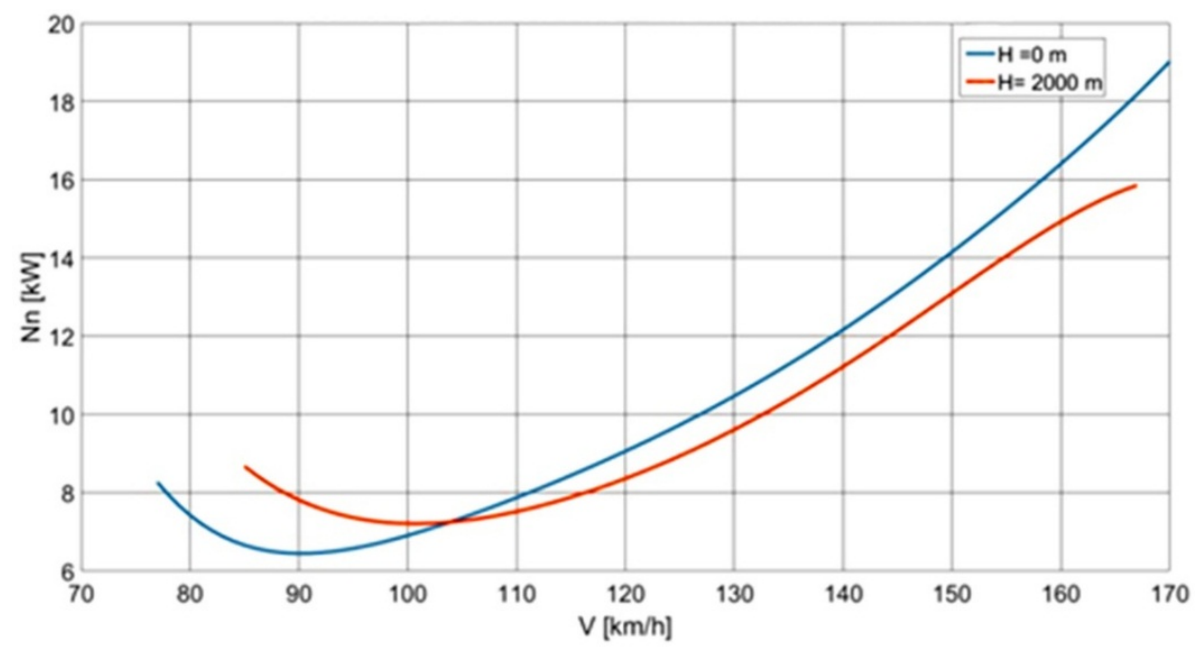

Fig. 2. The power required for flight of the AOS 71/H2 motor glider (take off mass $660 \mathrm{~kg}$ )

\section{The research procedure}

In order to compare the performance generated by the two power units, the appropriate flight trajectory was selected, which was depicted in Fig. 3 and 4. 


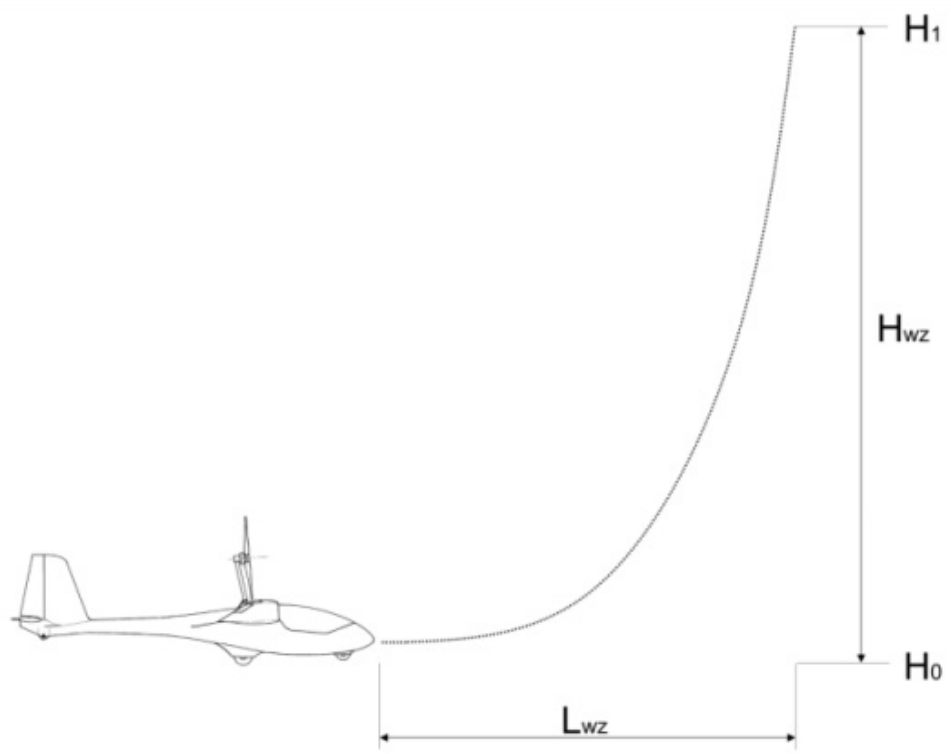

Fig. 3. Climb of the motor glider

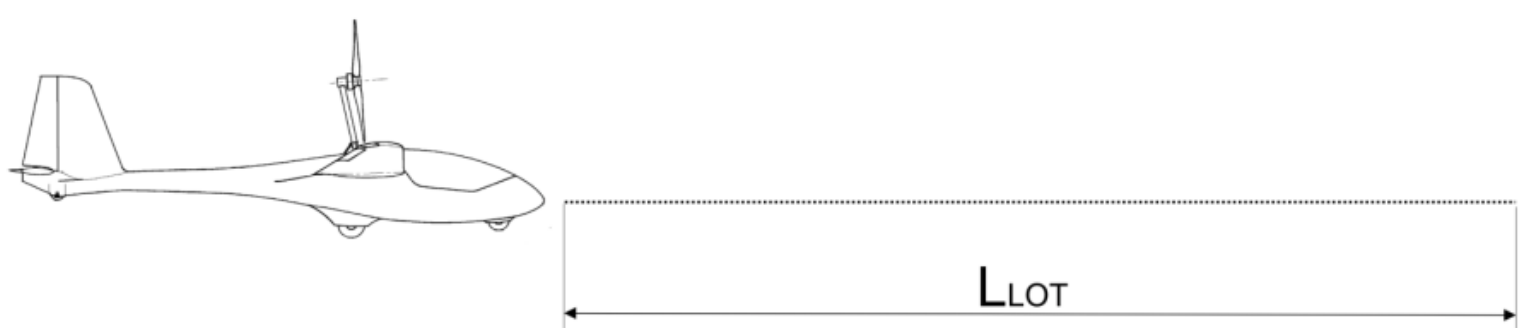

Fig. 4. Horizontal flight of the motor glider

Figure 3 presents the climb of the motor glider. The assumed climb altitude is $600 \mathrm{~m}$ at the horizontal velocity $\mathrm{V}=100 \mathrm{~km} / \mathrm{h}$ and the vertical velocity $\mathrm{V}=2.3 \mathrm{~m} / \mathrm{s}$. These parameters are the best for manoeuvring, and were selected based on the construction and technical documentation of the AOS motor glider. Fig. 4 presents the horizontal flight of the motor glider. The adopted flight speed is $100 \mathrm{~km} / \mathrm{h}$. To determine the flight range and durability, the energy method was used [1,3]. The procedure was presented in another publication of the authors [9].

\section{Selection of a distributed propulsion for the AOS H2 motor glider}

In order to compare the performance generated by the two propulsion units, the appropriate flight trajectory was selected, which is depicted in Fig. 3 and 4. Taking into account the aerodynamic parameters of the airframe and the maximum power developed by the classic power unit, ten BLDC AXI 8120/10 engines were selected for the distributed variant. Parameters of this engine are given in Tab. 2. Fig. 5 presents the visualization of the distribution of engines installed on the motor glider.

Tab. 2. Technical data of the AXI engine [11]

\begin{tabular}{|c|c|c|}
\hline Iin & $\mathrm{A}$ & $95(\max )$ \\
\hline$R m$ & $\Omega$ & 0.047 \\
\hline$U_{\text {in }}$ & $\mathrm{V}$ & $52(\max )$ \\
\hline$K v$ & $\mathrm{Rpm} / \mathrm{V}$ & 140 \\
\hline$I_{o}$ & $\mathrm{~A}$ & 1.2 \\
\hline
\end{tabular}




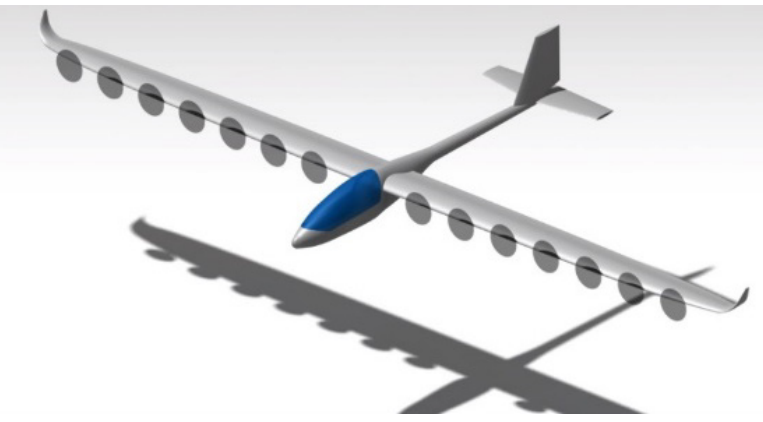

Fig. 5. Visualization of the distributed propulsion for the motor glider

Based on the technical data of the AXI 8120/10 engine, its rotational characteristics was determined, which is required for the selection of propellers. For this purpose, the formulas (1), (2) were used to determine the input and output power (received on the shaft) of the engine $[5,9,10]$. Voltage control was assumed, thanks to which maximum power and drive torque were available from the lower rotational range $[5,10]$.

To determine the engine characteristics, the following formulas were used:

$$
N_{\text {in }}=I_{\text {in }} \cdot V_{\text {in }}
$$

where:

$N_{i n}$ - power taken from the power source [W],

Iin - current intensity [A],

$U_{\text {in }}$ - voltage [V],

$$
N_{\text {out }}=\left(I_{\text {in }}-I_{o}\right)\left(V_{\text {in }}-R_{m} \cdot I_{\text {in }}\right),
$$

where:

$N_{\text {in }}$ - power received on the motor shaft [W],

Io - no load current [A],

$R_{m}$ - internal resistance $[\Omega]$,

$$
n=K v \cdot\left(V_{\text {in }}-R_{m} \cdot I_{\text {in }}\right),
$$

where:

$K v$ - engine impulse $[\mathrm{rpm} / \mathrm{V}]$,

$n$ - engine speed.

As a result, the rotational characteristics of the engine were obtained. The results obtained are shown in Fig. 6.

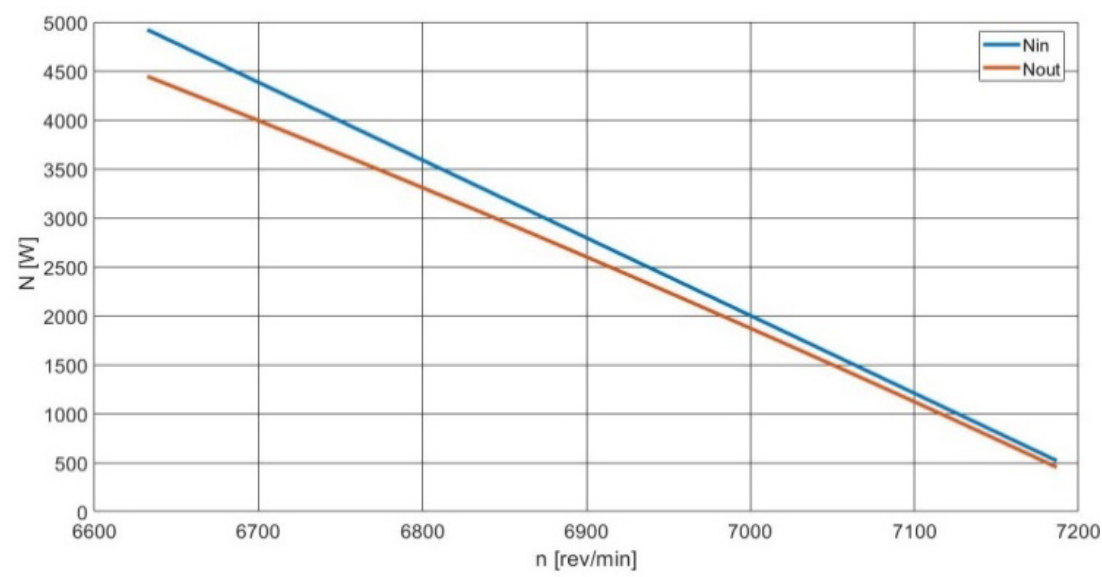

Fig. 6. The obtained characteristics of the electric motor 
For the obtained engine characteristics, the propellers of a small diameter were selected. The analysis uses the characteristics of a Clark Y2 propeller [3]. The selection procedure was as follows $[2,9]$ :

- determination of the engine power coefficient as a function of engine speed according to the formula:

$$
C_{n}=\frac{N_{\text {out }}}{\rho \cdot n^{3} \cdot D^{5}},
$$

where:

$C n$ - power coefficient [-],

$\rho-$ air density $\left[\mathrm{kg} / \mathrm{m}^{3}\right]$,

$n \quad-$ engine speed $[\mathrm{rad} / \mathrm{s}]$,

$D$ - propeller diameter $[\mathrm{m}]$;

- reading the power characteristic of the propeller corresponding to the value from the previous step,

- reading the advance ratio of the propeller. The propeller advance is determined by the formula:

$$
J=\frac{V}{n \cdot D}
$$

where:

$J$ - propeller advance [-],

$V$ - flight speed $[\mathrm{m} / \mathrm{s}]$.

$n$ - engine speed,

$D$ - propeller diameter [m].

Based on the flight speed with which the aircraft can move and the propeller rotations, using the formula (5), a propeller with a diameter ensuring the best performance parameters was selected;

- reading the $\mathrm{Cp}$ propeller thrust coefficient for selected diameter and the obtained $\mathrm{Cn}$ coefficient of the propeller. For the obtained $\mathrm{Cp}$, a propeller thrust was received from the formula:

$$
P=C_{p} \cdot \rho \cdot n^{2} \cdot D^{4}
$$

where:

$$
\begin{aligned}
& P-\text { thrust }[\mathrm{N}], \\
& C p-\text { thrust coefficient }[-], \\
& \rho-\text { air density }\left[\mathrm{kg} / \mathrm{m}^{3}\right], \\
& n-\text { engine speed, } \\
& D \quad-\text { propeller diameter }[\mathrm{m}] .
\end{aligned}
$$

The selected diameter of the propellers was $0.45[\mathrm{~m}]$.

Figure 7 presents a graphical procedure for the propeller selection, while in Fig. 8, the thrust generated by a distributed power unit (10 engines) compared to the thrust of the classic propulsion system of the AOS H2 motor glider.

As it can be noticed, the thrust generated at the same values of energy drawn from the power source is more favourable (about 20\% improvement in thrust in the speed range of the engine flight of the motor glider - i.e. up to $30 \mathrm{~m} / \mathrm{s}$ ).

On this basis, the analysis of the flight range and duration, as well as the hydrogen consumption by a distributed power unit was carried out.

\section{Comparison of performance achieved by the motor glider for both power units}

Applying the energy method developed by the authors $[3,8,9]$, there were determined: the flight range until the energy source was exhausted (Fig. 9), the corresponding flight duration (Fig. 10) and the hourly hydrogen consumption (Fig. 11). 

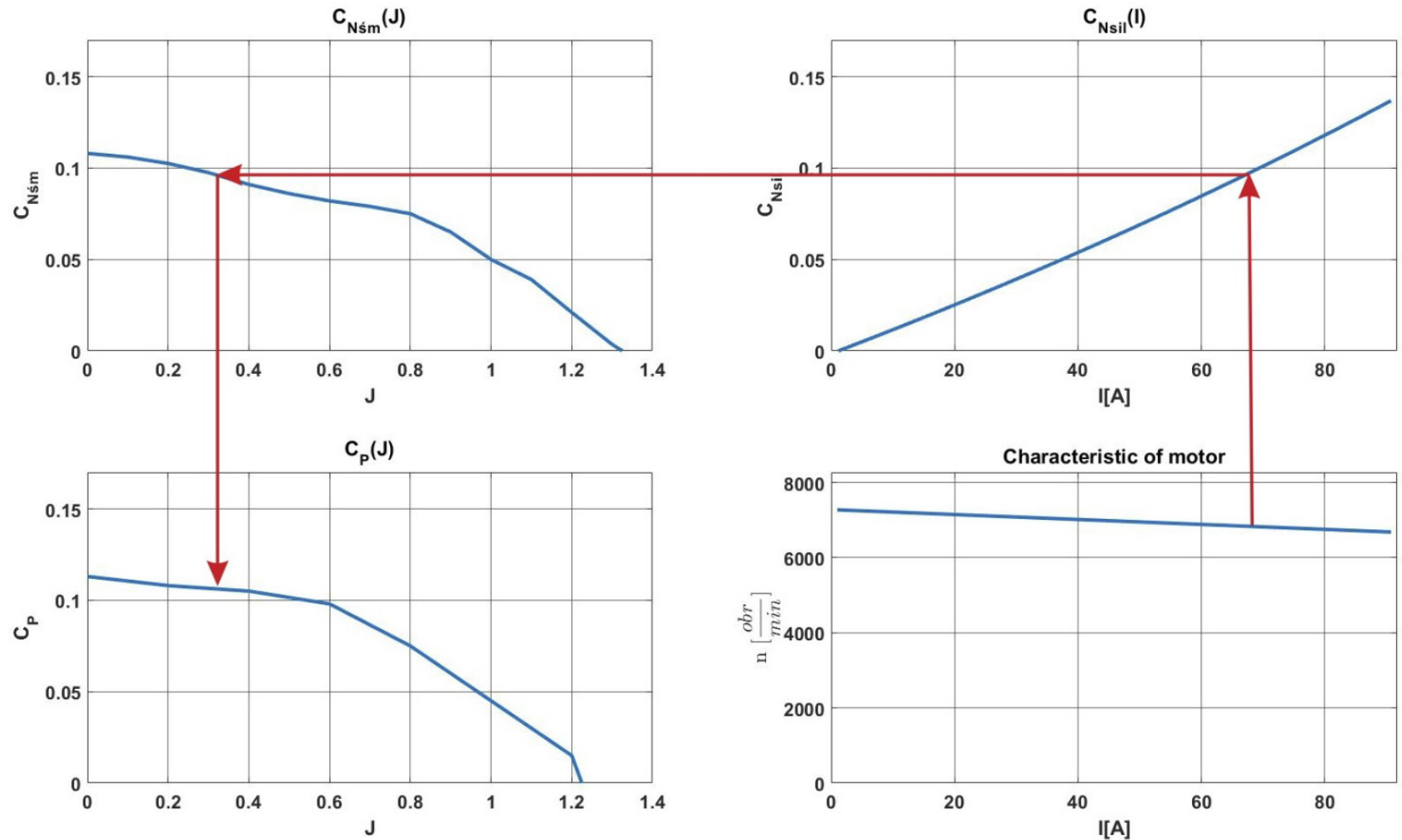

Fig. 7. The procedure of the propeller selection

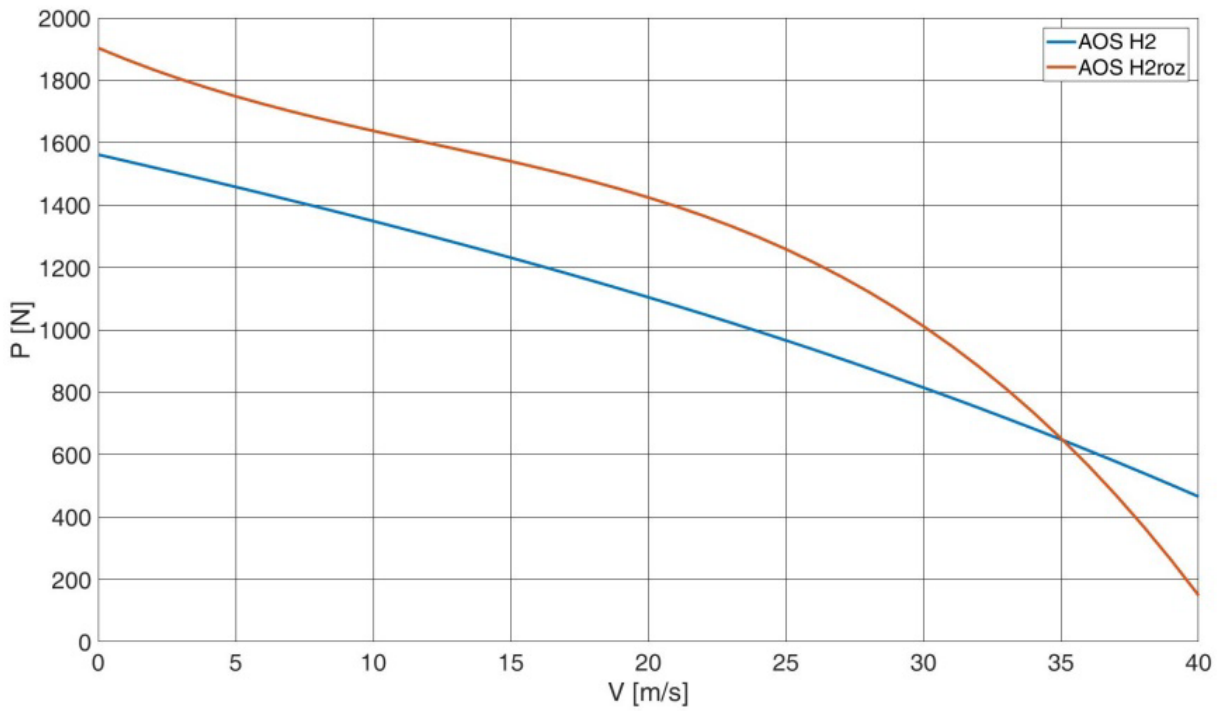

Fig. 8. Comparison of thrust generated by classic and distributed propulsion

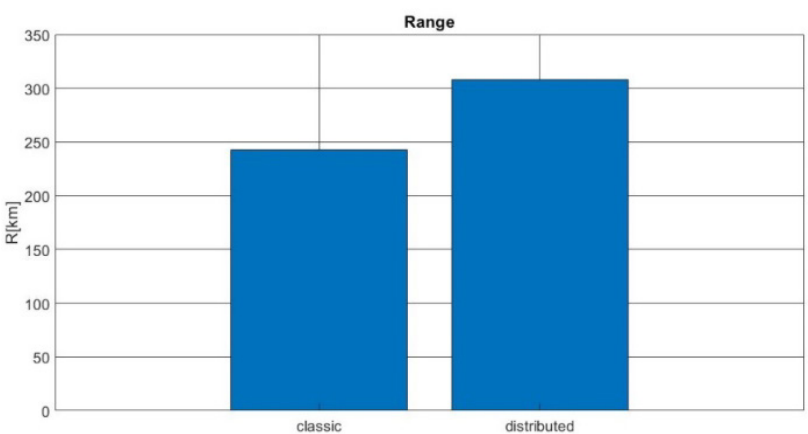

Fig. 9. The flight range

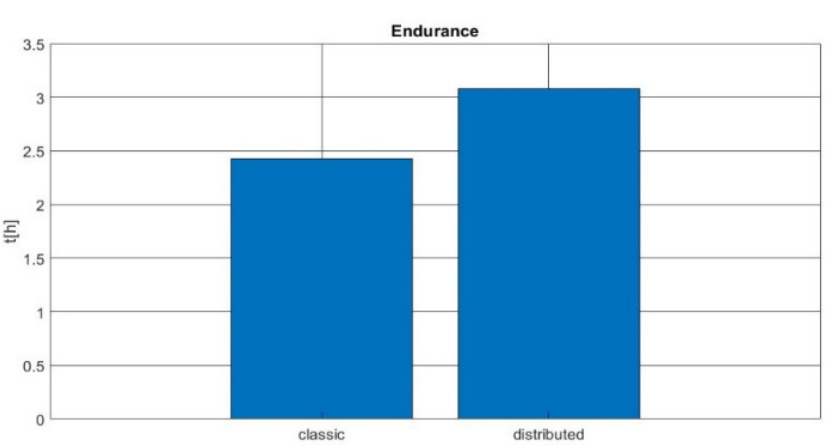

Fig. 10. The flight duration 


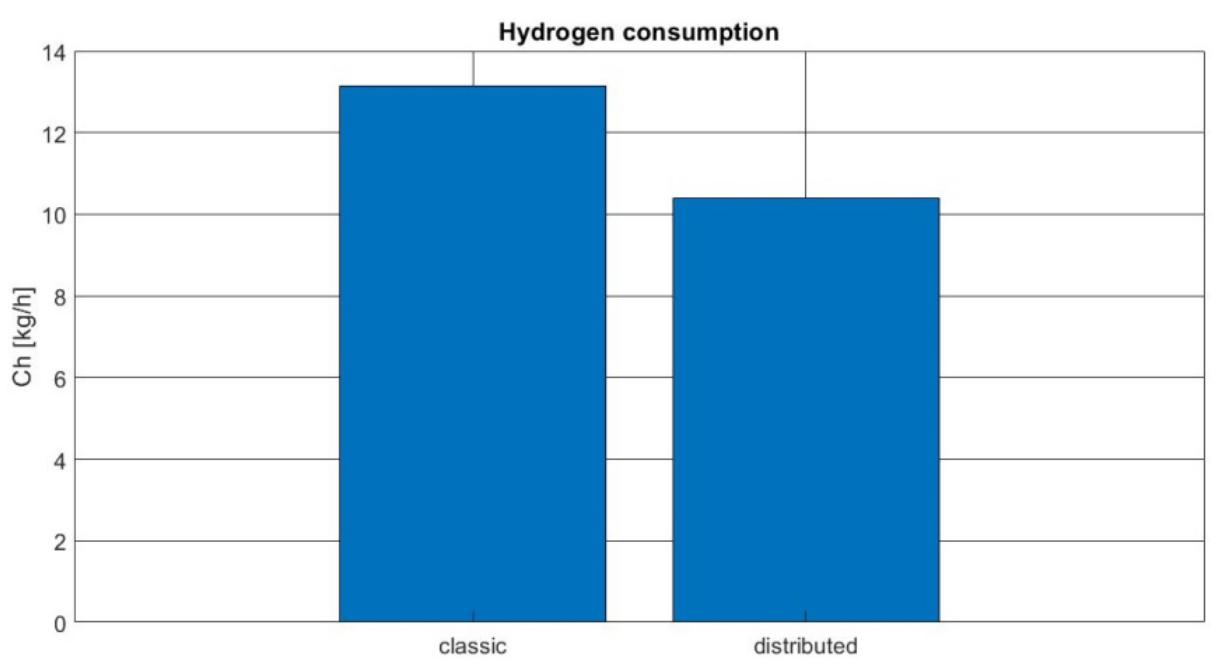

Fig. 11. The hourly hydrogen consumption

\section{Conclusions}

The purpose of the work undertaken in the paper was to demonstrate that distributed propulsion could bring noticeable benefits. For the adopted motor glider, the analysis of performance of both types of propulsion was performed. Applying the energy method, the range, flight durability and hydrogen consumption were determined.

The analysis carried out leads to the following conclusions:

1. For a motor glider equipped with the distributed propulsion, the flight range increased by 65 kilometres and the flight duration by 39 minutes, which gave $26.5 \%$ longer range and flight duration than in case of the classic propulsion.

2. In the case of distributed propulsion, hydrogen consumption decreased by $3 \mathrm{~kg}$ per one hour of flight. This constitutes a decrease in hydrogen consumption per one hour of flight by $28.5 \%$ when compared to the classic propulsion.

Based on these conclusions, it can be stated that distributed propulsion can improve the performance of the aircraft. An additional advantage will be the economic reasons - on the same energy stored, the aircraft will fly longer. Hourly fuel consumption will be lower, as the work of the propulsion system is distributed over a longer distance.

This analysis is a good predictor of subsequent research. The indicated lengthening of the flight range and the reduction of hourly hydrogen consumption, allows for a better disposal of energy accumulated on board. Thanks to the distributed propulsion, the hydrogen cell performance can be better exploited. In order to verify the benefits of a distributed propulsion accurately, a wider aerodynamic analysis would be needed - determining the interference between the propeller and the airframe, as well as the mutual influence of propeller blades on each other, and finally on the aircraft's performance during the flight.

\section{Acknowledgements}

The research presented in this paper was financed as project PBS3/A6/24/2015 "AOS-H2" of the Applied Research Programme (PBS) of the National Centre for Research and Development (NCBIR), Poland, in the years 2015-19.

\section{References}

[1] Anderson, J., Introduction to flight, McGraw Hill Book Company, San Francisco 2003.

[2] Bukowski, J., Łucjanek, W., Napęd śmigłowy teoria i konstrukcja, MON, Warszawa 1984. 
[3] Geiss, I., Voit-Nitschmann, R., Sizing of fuel-based energy systems for electric aircrafts, Proceedings of the Institution of Mechanical Engineers Part G-Journal of Aerospace Engineering, Vol. 231, 2017.

[4] Hartman, E., Biederman, D., The aerodynamic characteristic of full-scale propellers, NACA, Report No.640, 1938.

[5] Jakubowski, R., Orkisz, M., Wołoszyn, T., Wygonik, P., A review of selected alternative propulsion systems for UAV applications, Combustion Engines, Zeszyty Naukowe, Wyższa Szkoła Oficerska Sił Powietrznych, No. 1, 2015.

[6] Marianowski, J., Frączek, W. Czarnocki, F., Założenia podstawowe dla projektu motoszybowca AOS-H2.

[7] Marianowski, J., Tomasiewicz, J., Czarnocki, F., Analiza masowa motoszybowca AOS-H2.

[8] Orkisz, M., Wygonik, P., Kuźniar, M., Kalwara, M., Comparative analysis of pollutants emission by classical and distributed propulsions applied on the AOS motor glider, Combustion Engines, 179(4), pp. 102-106, 2019.

[9] Orkisz, M., Wygonik, P., Kuźniar, M., Kalwara, M., Propulsion of an electric generator in application to a motor glider propulsion, Combustion Engines, 178(3), pp. 281-285, 2019.

[10] Wołoszyn, T., Jakubowski, R., Orkisz, M., Wygonik, P., Analysis of integration capabilities of hybrid-electric propulsion system in an unmanned aerial vehicle for a determined mission, Combustion Engines, 154(3), pp. 556-561, 2013.

[11] www.modelmotors.cz.

Manuscript received 21 March 2019; approved for printing 24 June 2019 